\title{
GUARANTEEING THE TROUBLE-FREE OPERATION OF CAPACITOR BANKS IN POWER-SUPPLY SYSTEMS OF INDUSTRIAL ENTERPRISES
}

\begin{abstract}
Purpose. The problem of resonance phenomena in power systems of industrial enterprises using capacitor banks for reactive power compensation was detected. Circuit of the capacitor banks tier to downshift main substation tires is present. But there is no common algorithm to calculate and avoid such trouble. The main goal of this article is to introduce some basics for power supply systems with possible resonant circuits engineering. Methodology. At the first step the data on the change of the current in the chemical company network when changing capacitor banks value are received. For these purposes the oscilloscope function of digital protection relay was used. Current data samples were analyzed by spectrum detection software. Most significant levels of the 3rd and 5th harmonics were achieved. Comparison of harmonic distortion levels with and without capacitor bank is given. Results. Achieved data allow making conclusion about overloading reasons of capacitor banks while higher harmonics currents presence. A voltage and current harmonious composition measuring in the absence of power quality analyzers using digital protection relay terminals or emergencies registers are proposed. The necessity of power quality monitoring near capacitor banks connections to avoid resonance phenomena (current and voltage resonance) in industrial power supply systems is proven. The control algorithm of capacitor banks to provide electromagnetic compatibility, while various modes of nonlinear load operation is given. Originality. Using of digital protection relay oscilloscoping for current resonant detection can allow to significally reduce time and cost of solution. Replacement parallel circuit comprising a branch and one active-inductive load to another branch network in the presence of higher harmonics source are proposed. Practical value. A sequence for measuring the levels of harmonic components at the connections of capacitor banks in the absence of specialized instruments is proposed. The algorithm to avoid possible resonance currents in the presence of condensing units is proposed. References 9, tables 2, figures 2. Key words: power supply system, resonance, capacitor bank, power quality, electromagnetic compatibility.
\end{abstract}

В статье рассматривается проблема резонансных явлений в системах электроснабжсения промыцленных предприятий, использующих конденсаторные установки для компенсации реактивной мощности. Приведены данные по изменению токов 3-й и 5-й гармонических составляющих в сети химического предприятия при изменении мощцости присоединенных конденсаторных установок. Предложен способ измерения качества электроэнергии при отсутствии анализаторов. Разработан алгоритм обеспечения электромагнитной совместимости на присоединениях конденсаторных установок. Библ. 9, табл. 2, рис. 2.

Ключевые слова: система электроснабжения, резонанс, конденсаторные установки, качество электрической энергии, электромагнитная совместимость.

Problem definition. In some cases in power-supply systems of industrial enterprises dangerous resonant phenomena can arise. For example, at simultaneous utilization of the smooth soft start device which includes a semiconductor converter and a capacitor bank, the failure resonant currents able to destroy the capacitor bank as well as the whole power supply-system were fixed [1]. Generally, we can speak that the phenomenon of the current resonance is inherent for power-supply systems to which nonlinear customers and devices of reactive power compensation are connected simultaneously. Trends of the modern electrical customers' development permit to speak that power and number of used semiconductor converters increase permanently. Devices of reactive power compensation including capacitor banks become more and more widely used. So, a task of the capacitor banks and, in general, power supply systems of industrial enterprises protection from resonant phenomena is actual. There is necessity to develop methods and techniques to improve electromagnetic compatibility of power supply systems of industrial enterprises.

Analysis of last investigations and publications. In [2] it is noted that resonance arising on the substation's buses results in sharp increase of the current, mainly by sharp increase of its harmonic components in the resonance circuit. In [3] it is determined that in the circuit including capacitor bank in one loop and active-inductive load in another one, voltage resonance in addition to current one can arise. A technique of the calculation of the resonant frequency in such a circuit is proposed in [4].
Ya.E. Shklyarskiy and A.N. Skamin have determined the dependence of the capacitor bank's overload factor on compensating devices' power, power of linear and nonlinear loads, spectra of current and voltage. Besides, assessment of the power grid's parameters at various conditions of arising of higher harmonics which guarantees the capacitor bank operation without overload is presented [5].

The goal of the paper: to develop a methodology of measurement of harmonic components on capacitor banks' connections and propose measures to prevent current resonance in power supply systems of industrial enterprises which include capacitor banks.

Main research material. Operational regulations for exploitation of consumers' electrical installations [6] recommend that on the medium voltage capacitor installations' connections on-line monitoring of the electrical energy quality parameters should be carried out, and on the low voltage capacitor installations' connections such measurements should be carried out periodically. To do it, it is necessary to use specialized analyzers of the electrical energy quality. A lot of worldwide manufacturers develop and produce such devices. However, they are very expensive, so utilization of such devices in power supply systems of industrial enterprises requires huge expenses. High price of electrical energy quality analyzers is determined mainly by utilization of high-technological elementary base that is necessary to guarantee high requirements for the measurement's

(C) D.A. Gapon, Ya.S. Bederak 
precision. However, the presence of the high accuracy is not principal to determine and analyze the resonance. So, in the case of the absence of specialized measurement devices it is possible to measure the voltage and current harmonic compositions by using microprocessor terminals of the relay protection or fault recorders which have the accuracy class 0.5 for current and voltage measurement. Mainly they have a function of the registration of current and voltage oscillograms at arbitrary time. However, it is necessary to note that some terminals of relay protection (for example, by Siemens) use preliminary signal processing by using an analog band filter to extract first harmonic. It is obvious that in this case information about presence and parameters of higher harmonics losses. Therefore, before the oscillograms registration it is necessary to be sure that the device is able to save necessary spectral components. Obtained data are converted in the COMTRADE format which is open and described in the free Standard permits to proceed information by using a wide spectra of computer codes. There are developments by Siemens, Aniger, Hartron, Uniti and other Companies. Most of codes permits to carry out computations of higher harmonic components of current and voltage.

One-line diagrams of the capacitor bank $6 \mathrm{kV}$ No. 1, 2 are presented in Fig. 1, 2 respectively.

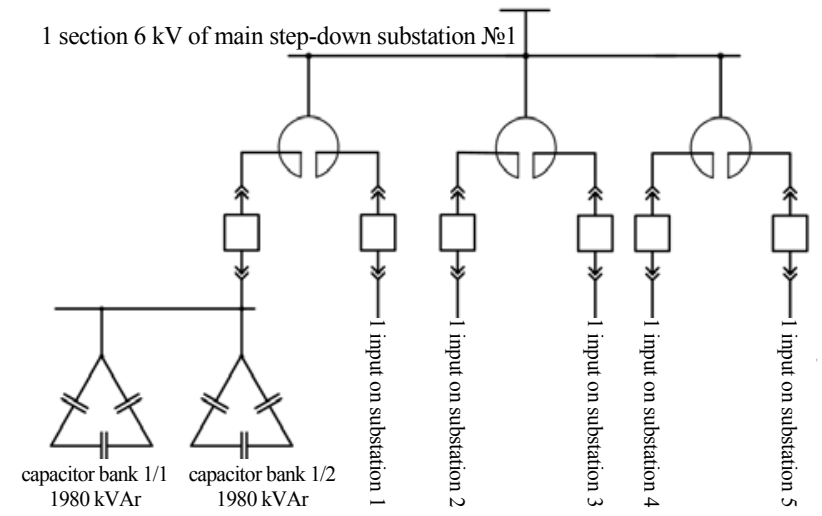

Fig. 1. One-line diagram of the capacitor bank No. 1 connection to buses $6 \mathrm{kV}$ of the main step-down substation of the industrial enterprise

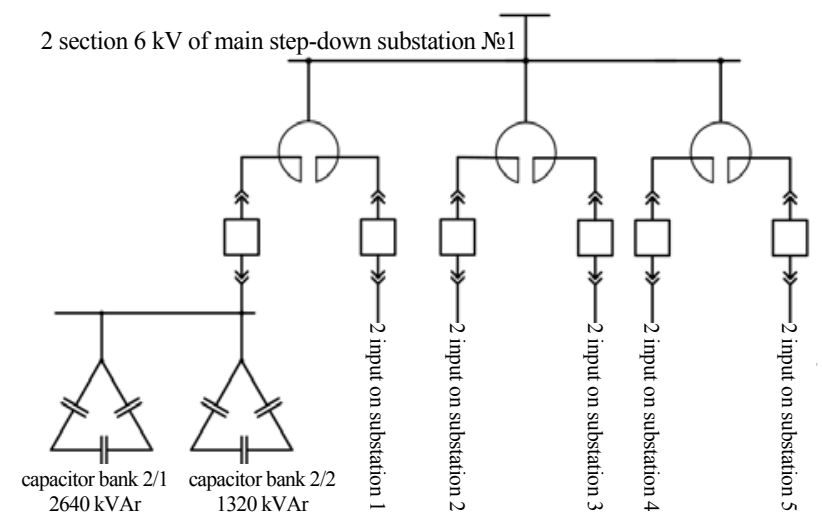

Fig. 2. One-line diagram of the capacitor bank No. 2 connection to buses $6 \mathrm{kV}$ of the main step-down substation of the industrial enterprise

Measurement was carried out on the capacitor bank's connections of $6 \mathrm{kV}$ which are used for the reactive power compensation on the bus section of the step-down substation at the chemical enterprise. In Tables 1,2 values on $n$-th harmonic components on buses of the capacitor banks No. 1, 2 are respectively presented. It is necessary to note that in both case amplitude of the $3^{\text {rd }}$ voltage harmonic does not exceed $4 \%$, and amplitude of the $5^{\text {th }}$ harmonic component isles than $5 \%$ that is permissible in the correspondence with the Sate Standard GOST 13109 - 97 [7].

Table 1

Values of coefficients of the $n$-th current harmonic component in percent before and after the capacitor bank No. 1 connection

\begin{tabular}{|c|c|c|c|c|}
\hline \multirow{2}{*}{$\begin{array}{c}\text { Harmonic } \\
\text { No. }\end{array}$} & $\begin{array}{c}\text { After the capacitor unity } \\
\text { connection } \\
\text { (partial connection) }\end{array}$ & $\begin{array}{c}\text { After the capacitor unity } \\
\text { connection } \\
\text { (full) }\end{array}$ \\
\cline { 2 - 5 } & $\begin{array}{c}\text { Current of } \\
\text { the phase } \\
\text { A }\end{array}$ & $\begin{array}{c}\text { Current of } \\
\text { the phase C }\end{array}$ & $\begin{array}{c}\text { Current of } \\
\text { the phase A }\end{array}$ & $\begin{array}{c}\text { Current of } \\
\text { the phase C }\end{array}$ \\
\hline 3 & 0.7 & 0.41 & 0.74 & 0.44 \\
\hline 5 & 8.95 & 6.63 & 26.00 & 18.78 \\
\hline
\end{tabular}

Results of measurements prove that at the change of the connected capacitor bank's power (see Table 1, 2) currents of higher harmonic components can arise essentially exceeding permissible normative values [8] resulting in the capacitor bank's overload. In the same time load on connections can vary widely. Depending on the value of the inductive load the current resonance at the frequency of one or another current harmonic can arise. To prevent such situations it is necessary to change the capacitor bank's connected capacity in such a way that the quiescent frequency of the oscillation circuit do not coincide with the frequency of one of any present higher harmonics. It is necessary to note that realization of such a adjustment requires huge investigations at the first stage of which it is necessary to collect a lot of information about resonant phenomena in power-supply systems of industrial enterprises. Therefore, there is an actual necessity to organize monitoring of the electrical energy quality on the capacitor bank's connections. Proceeding of data collected in such a way will permit to guarantee in the future electromagnetic compatibility of capacitor banks independently on the composition and character of the network loading [9].

Table 2

Values of coefficients of the $n$-th current harmonic component in percent before and after the capacitor bank No. 2 connection

\begin{tabular}{|c|c|c|c|c|}
\hline \multirow{2}{*}{$\begin{array}{c}\text { Harmonic } \\
\text { No. }\end{array}$} & \multicolumn{2}{|c|}{$\begin{array}{c}\text { After the capacitor unity } \\
\text { connection } \\
\text { (partial connection) }\end{array}$} & \multicolumn{2}{|c|}{$\begin{array}{c}\text { After the capacitor } \\
\text { unity connection } \\
\text { (full) }\end{array}$} \\
\cline { 2 - 5 } & $\begin{array}{c}\text { Current of } \\
\text { the phase A }\end{array}$ & $\begin{array}{c}\text { Current of } \\
\text { the phase } \\
\text { C }\end{array}$ & & $\begin{array}{c}\text { Current of } \\
\text { the phase } \\
\text { A }\end{array}$ \\
\hline 3 & 1.06 & 0.76 & 0.59 & 0.48 \\
\hline 5 & 13.7 & 10.65 & 8.9 & 2.29 \\
\hline
\end{tabular}

So, to prevent resonant phenomena on the capacitor banks' connections the following sequence of actions is proposed:

1. Measurement of parameters of electrical energy quality on the capacitor banks' connections.

1.1. Measurement of parameters of electrical energy quality on the capacitor banks' disconnected connections (determination of the voltage harmonic set). 
1.2. Measurement of parameters of electrical energy quality on each stage of the capacitor bank from minimal power to full power of the capacitor bank.

2. Proceeding of the measurement results. Determination of the capacitor bank's power at which there is essential increase of the coefficient of the $n$-th current harmonic component.

3. Determination of sources of nonlinear distortions influencing on the electrical energy quality.

4. Building an equivalent circuit of the parallel one which includes the capacitor unit in one loop and activeinductive load in another one at presence a higher harmonics source in the network.

5. Calculation of the resonance frequency and the pass band in the circuit.

6. Decrease of the capacitor bank's power at the coincide of the resonance frequency in the circuit with the frequency of odd higher harmonics divisible by $50 \mathrm{~Hz}$.

7. Check of the possibility of resonance phenomena arising in the mode of the nonlinear load start at presence of the higher harmonics source in the network that is connected for short time [1].

\section{Conclusions.}

1. It is propose to measure the voltage and current harmonics set струму at the absence of electrical energy quality analyzers by using microprocessor relay protection terminals or by fault recorders.

2. Necessity of organization of the electrical energy quality monitoring on the capacitor banks' connections to prevent resonance phenomena (current and voltage resonance) in power-supply systems of industrial enterprises is proved.

3. An algorithm to guarantee the electromagnetic compatibility on the capacitor banks' connections which can work in the mode of the nonlinear load start as well as in the mode of steady operation of electrical load.

\section{REFERENCES}

1. Gapon D.A., Bederak Ya.S. Features of the operation regime of the mains during soft start of powerful synchronous motors. Promyshlennaia energetika - Industrial Power Engineering, 2014, no.2, pp.27-30 (Rus).
2. Beliy V.B. Electromagnetic compatibility of power-supply systems' elements comprising reactive power compensation devices. Vestnik Altaiskogo Gosudarstvennogo Agrarnogo Universiteta - Bulletin of the Altai State Agrarian University, 2009, no.6, pp. 62-65 (Rus).

3. Bederak Y.S., Oleynik S.V., Shuliak A.A. Research of capacitors mode 6 (10) $\mathrm{kV}$ connected to branches of dual limiting current reactor. Elektromekhanichni i enerhozberihaiuchi systemy - Electromechanical and energy saving systems, 2013, vol.2, part 2, pp. 290-294. (Ukr).

4. Bederak Y.S. Electromagnetic compatibility of complex industrial power supply systems Visnyk NTU «KhPI» - Bulletin of $N T U$ «KhPI», 2014, no.60, pp. 37-45. (Ukr).

5. Shklyarskiy Ya.E., Skamin A.N. Industrial research into high harmonic influence on compensation devices. Elektrotekhnika i elektromekhanika - Electrical engineering \& electromechanics, 2013, no.1, pp. 69-71 (Rus).

6. Rules of technical operation of electrical consumers, approved by the Ministry of Fuel and Energy of Ukraine 25.07.2006, no.258 (as amended by Order of the Ministry of Energy and Coal Industry of 13.02.2012 no.91) with amendments, approved by the Ministry of Energy and Coal Industry of Ukraine 11.16.2012 no.905. (Ukr).

7. State Standard 13109-97. Electric Energy. Compatibility of technical equipment. Standards of quality of electric energy in power systems for general use. Interstate standard. Moscow, IPC Standards Publ., 1998. 31 p. (Rus).

8. IEEE Standard 519-1992. IEEE recommended practices and requirements for harmonic control in electrical power systems. $-100 \mathrm{p}$.

9. Bederak Y.S. Current and voltage monitoring implementation with varying load character in the branches of twin reactor in the presence of higher harmonics sources. Enerhetyka ta elektryfikatsiia - Energetic and electrification, 2013, no.8, pp. 48-51 (Ukr).

Received 09.10.2015

D.A. Gapon ${ }^{1}$, Candidate of Technical Science, Associate Professor, Ya.S. Bederak', Engineer,

${ }^{1}$ National Technical University «Kharkiv Polytechnic Institute», 21, Frunze Str., Kharkiv, 61002, Ukraine.

phone+38057 7076551, e-mail: dima12345ml@mail.ru

${ }^{2} \mathrm{PJSC} \ll \mathrm{AZOT} »$,

72, Pervomayskaya Str., Cherkassy, 18014, Ukraine. phone +38047 2392979, e-mail: ei@uch.net 